\title{
MOST PEERS DON'T BELIEVE IT, HENCE IT IS PROBABLY FALSE
}

\author{
RENÉ VAN WOUdENBERG \& HANS VAN EYGHEN \\ VRIJE UNIVERSITEIT AMSTERDAM
}

\begin{abstract}
Rob Lovering has recently argued that since theists have been unable, by means of philosophical arguments, to convince 85 percent of professional philosophers that God exists, at least one of their defining beliefs must be either false or meaningless. This paper is a critical examination of his argument. First we present Lovering's argument and point out its salient features. Next we explain why the argument's conclusion is entirely acceptable for theists, even if, as we show, there are multiple problems with the premises.
\end{abstract}

\section{THE 'NUMBERS COUNT' ARGUMENT STATED}

In the recent discussion over peer disagreement, i.e. disagreement between parties that are equally apprised of the relevant evidence, equally capable of evaluating it, and equally aware of the disagreeing other, two positions stand out. First there is the 'conciliatory' view according to which, roughly speaking, ${ }^{1}$ awareness of a disagreeing peer is evidence against one's own view - and a reason to change it in some way. ${ }^{2}$ Second there is the 'steadfast' view according to which, roughly speaking, awareness of a disagreeing peer is not evidence against one's own view - and no reason to change it. Rob Lovering has recently argued for something like a third position in the disagree-

1 A much more precise presentation and discussion of the two views is Bryan Frances, Disagreement (Polity, 2014).

2 Various suggestions have been made as to what sort of change is called for. See, for instance, David Christensen, "Epistemology of Disagreement: The Good News", The Philosophical Review 116, no. 2 (2007) (disagreeing peers should 'move to one another'), Hilary Kornblith, "Belief in the Face of Controversy", in Disagreement, ed. Richard Feldman and Ted A. Warfield (OUP, 2010) (disagreeing peers should go agnostic). 
ment debate. The core of this position is that numbers count: the more peers don't believe $\mathrm{p}$, the more reason we have to think that $\mathrm{p}$ is false. If many peers don't believe $p$, the proper conclusion to draw is that $p$ is probably false. This paper is an examination of Lovering's case for this 'numbers count' position.

Lovering argues that the mere fact that the friends of theistic arguments have failed to convince a majority of professional philosophers discredits their view. He summarizes his argument as follows:

The very existence of [nontheistic philosophical] epistemic peers makes it clear that theistic inferentialists have failed to make the inferential case for theism to them. And that they have failed to do so is a problem [...] I refer to this as the "problem of the theistic inferentialists". [...] I shall then argue that of the most plausible possible solutions to this problem - each is either inadequate or incompatible with theistic inferentialist's defining beliefs. Thus, I conclude that the problem of the theistic inferentialists [...] is a problem for the theistic inferentialists - an objection to their defining beliefs. ${ }^{3}$

To get a clear view of the argument ${ }^{4}$, elaboration is required. First, who are the theistic inferentialists and what are their defining beliefs? Lovering is very clear about this: theistic inferentialists are theists "who are or were professional philosophers or who have or had enough philosophical training to be one." $\mathrm{He}$

3 Rob Lovering, God and Evidence: Problems for Theistic Philosophers (Bloomsbury, 2013), 21. The argument we shall be discussing is the substance of ibid., ch. 2; the chapter incorporates much material from Rob Lovering, "The Problem of the Theistic Evidentialist Philosophers", Philo 13, no. 2 (2010). What Lovering 2013 refers to as 'theistic inferentialists' is the same group of persons as what Lovering 2010 refers to as 'theistic evidentialist philosophers'.

4 Lovering's argument is the first argument in a larger philosophical project that contains five more arguments against (or problems for) various forms of theism (see Lovering, God and Evidence.). His second argument states that the fact that noninferential evidence for God's existence (i.e. religious experiences) is scarcely apprehended, is a problem for theistic noninferentialists (i.e. theists who believe that there is noninferential probabilifying evidence for God that is discoverable in practice). His third argument is aimed at theistic fideists (i.e. theists who believe that there is no discoverable probabilifying evidence for God's existence but believe that it's nonetheless morally acceptable to have faith that God exists). Lovering argues that having such faith without evidence can result in endangering, harming, and/or violating the rights of others. Lovering's fourth and fifth argument are aimed at all theists. The fourth states that skeptical theism (the claim that our cognitive abilities are too limited to make claims about what God does or will do) casts doubt on theistic claims. The fifth states that divine omniscience is impossible because God cannot know what it is like not to know. In this paper we focus exclusively on Lovering's first argument because, arguably, most theists adopt (some form of) theistic inferentialism. We also believe this argument is his most original one.

5 Ibid., 4. 
mentions the millennia-old tradition to which belong such philosophers as St. Augustine, Anselm, Thomas Aquinas, William Paley, Richard Swinburne, Alvin Plantinga, Robin Collins, and William Lane Craig. ${ }^{6}$ Their defining beliefs, he says, are

(a) that God exists,

(b) that there is inferential probabilifying evidence of God's existence,

(c) that this evidence is discoverable not simply in principle, but in practice. ${ }^{7}$

Lovering indicates that the phrase "discoverable not simply in principle, but in practice" means to rule out scenarios in which the evidence exists but is inaccessible to humans. An example of such a scenario is the existence of a goblet, the evidence for which is a sound that lies outside the range in which humans can hear. This evidence, he says, is discoverable in principle, but not in practice. ${ }^{8}$

Second, the summary statement says that

theists have failed to make the inferential case for theism" to their non-theistic philosophical peers. The evidence adduced for this is that "according to a recent survey of 931 philosophy faculty members, 15 percent accept or lean toward theism, 73 percent accept or lean towards atheism ('religious sceptics'), and the rest accept or lean toward the 'other' category (of which some undoubtedly accept or lean towards agnosticism). Since accepting or leaning toward atheism or 'other' involves not accepting or leaning toward theism, an overwhelming 85 percent of these philosophy faculty members do not accept or lean toward theism. ${ }^{9}$

6 And so, if theistic inferentialists failed to convince non-theists, it is not for lack of trying. Lovering's reference to the long history of theistic arguments is meant to make the argument intuitively all the more compelling. And in a way it does. An argument that has been around for a long time and has not convinced, say, $85 \%$ of its intended audience, is worse off than a relatively new argument that has not convinced $85 \%$ of its intended audience. In the case of theistic arguments this matter is complicated by the fact that there are so many different 'kinds' of theistic arguments (cosmological, ontological, moral, design arguments, among others) and that each 'kind' of argument has seen so many different 'versions' - some of which are relatively new. This is a point we deal with in section 2(b), where we discuss premise P2.

7 Ibid., 20.

8 Lovering, "The Problem of the Theistic Evidentialist Philosophers", 2.

9 Lovering, God and Evidence, 2. Lovering's source is the survey that was eventually published as David Bourget and David J. Chalmers, "What do philosophers believe?", Philosophical Studies: An International Journal for Philosophy in the Analytic Tradition 170, no. 3 (2014); preliminary versions of this survey have been available on the internet. Lovering, God and 
Third, the summary statement of the argument says that the most plausible explanations as to why theistic evidentialists have not convinced 85 percent of their peers, are problematic for or incompatible with the theistic inferentialist's defining beliefs. Lovering deems the following explanations to be the most plausible ones ${ }^{10}$ :

\#1 Nontheistic philosophers are intellectually inferior to theistic philosophers when it comes to evaluating the inferential evidence for God's existence.

\#2 Nontheistic philosophers are culpably ignorant of the inferential evidence for God's existence.

\#3 God prevents nontheistic philosophers from noticing the inferential evidence for God's existence.

\#4 Theistic philosophers have been unable to adequately articulate the inferential evidence for God's existence.

\#5 At least one of the theistic inferentialists' defining beliefs is false.

\#6 At least one of the theistic inferentialists' defining beliefs is cognitively meaningless. ${ }^{11}$

Lovering next argues that explanations \#1-\#4 are inadequate, whereas explanations \#5 and \#6 adequate. This means, of course, that \#5 and \#6 are

Evidence, 23, fn. 2 refers to http://philpapers.org/suveys/results.pl?affil=Target+faculty\&areas $0=0$ \&areas_max $=1 \&$ grain $=$ coarse.

10 Ibid., 25-38.

11 Lovering's list of explanations is in fact longer. He also lists three solutions that all involve the claim that theists lack inferential evidence. The three solutions differ in what is added to this claim, viz. (i) that the lack is not a problem, since theists may find such inferential evidence in the future, or (ii) that the lack is not a problem, since nontheistic philosophers don't have evidence for the non-existence of God that has silenced the theistic philosophers, or (iii) that the lack is not a problem, since agreement among philosophers is rare anyway. We have edited the list in the body of the text for obvious reasons: the three omitted explanations are all instances of explanation \#5- as they go against the theistic inferentialist's defining belief (b), according to which there is inferential probabilifying evidence for God's existence. We are assuming that the theistic inferentialist in believing (b) and (c) must also be held to believe that he possesses the evidence. If he were not held to believe this, he can hardly be charged for not having convinced $85 \%$ of his peers. One cannot convince someone else by evidence that one doesn't possess (but merely believes to exist). 
supposed to be better explanations than the others. This may not mean that \#5 and \#6 are supposed to be the best explanations full stop, but it does mean that they are the best of the set.

Given these clarifications we can now state Lovering's argument somewhat more precisely as follows:

P1: Theistic inferentialists have failed to convince an overwhelming majority (viz. 85 percent) of their intellectual peers.

P2: The best explanation of the fact stated in P1 is that at least one of the theistic inferentialists' defining beliefs is false or meaningless.

C: Therefore, it is probably true that at least one of the theistic inferentialists' defining beliefs is false or cognitively meaningless.

This argument is an inference to the best explanation. As a number of authors have noted, saying that $\mathrm{E}$ is the best explanation of fact $\mathrm{F}$ does not establish the truth of $\mathrm{E}$, nor that $\mathrm{E}$ is probably true, it only renders $\mathrm{E}$ more probable than its competitors. For all we know the best explanation may be "the best of a bad lot", to use Van Fraassen's expression. ${ }^{12}$ This may be so because the list of possible explanations is not exhaustive, and hence additional explanations might be better than those not coming out best. One may want to fault Lovering's argument simply for being an inference to the best explanation. Since such criticism is not new and would not have anything in special to do with Lovering's argument, we won't pursue it further.

Should we be convinced by this argument? The first thing to see is that the argument is formally valid: if the premises are true and acceptable, then so is the conclusion. But are the premises true and acceptable? We argue they are not.

12 Bas C. van Fraassen, Laws and symmetry (Clarendon Press, 1989), 143; an overview of other criticisms of inferences to the best explanation can be found in Igor Douven, "Abduction", in The Stanford Encyclopedia of Philosophy, ed. Edward N. Zalta, Spring 2011, http:// plato.stanford.edu/archives/spr2011/entries/abduction/, section 3.1; Peter Lipton, "Is the Best Good Enough?", Proceedings of the Aristotelian Society 93 (1993). 


\section{THE ARGUMENT EXAMINED}

\section{a. The Argument's Conclusion}

We begin our examination by considering the argument's conclusion. This conclusion is such that it could be true in many different ways, since each of the inferentialist's defining beliefs (a), (b), or (c) could be false or meaningless. In this section we argue, first, that not all the ways in which the conclusion could be true, are equally damaging for the theistic inferentialist, and second, that the theist's presumed defining belief (c), i.e. "that the evidence for God's existence is discoverable not simply in principle, but in practice", is problematic independently of religious concerns one might have.

The argument's conclusion could be true in various different ways. Let us canvass the possibilities. Are any of the inferentialist's defining beliefs (a), (b), and/or (c) meaningless? They certainly look meaningful: they are intelligible, we can envision what would have to be the case if they were to be true, we can draw inferences from them, etc. And Lovering's 12-sentence discussion of this matter ${ }^{13}$ gives no reason to take the possibility that (a), (b), and/ or (c) are meaningless seriously. Even Lovering doesn't seem to think that (b) and (c) are meaningless. For he seems to be implying that there is no probabilifying evidence for God's existence - something he can only say if he thinks that (b) is a meaningful proposition. And he clearly thinks that (c) is meaningful - for, as we noted, he even explains its meaning. As to (a): of course, Neopositivists like A.J. Ayer thought the statement "God exists" is meaningless. ${ }^{14}$ But they adopted the verification criterion of meaning that, as Plantinga once said, has receded into the obscurity it so richly deserves. ${ }^{15}$ It has so receded for a number of reasons none of which Lovering even tries to refute or undermine. Hence we feel justified to put the "meaningless" part of the conclusion to one side.

This means that the argument's conclusion could be true if at least one of the inferentialist's defining beliefs is false. Hence, if an theistic inferentialist is to be convinced by Lovering's argument, at least one of her defining beliefs

\footnotetext{
13 Lovering, God and Evidence, 38.

14 Alfred Jules Ayer, Language, Truth and Logic (Dover Publications, 2012 [1952]).

15 See Alvin Plantinga, God and other Minds: A Study of the Rational Justification of Belief in God (Cornell Univ. Press, 1967).
} 
must be shown to be false. We shall now argue that not all the ways in which the argument's conclusion could be true, would, if true, be equally damaging for the inferentialist qua theist. It would be quite damaging if the inferentialist qua theist were forced to give up (a), theism. If an inferentialist theist were forced to give up one of her defining beliefs, she would almost certainly not opt for (a). How great would the damage be if she were to retain (a), but reject (b)? The damage would be smaller for she would still be a theist. Inspired by Alvin Plantinga's 'Reformed Epistemology', for example, she might adopt the idea that belief in God can be entirely rational and proper even in the absence of inferential, propositional, probabilifying evidence. ${ }^{16}$ She would then, of course, no longer be an theistic inferentialist as defined by Lovering, but still a theist. If an inferentialist were to drop belief in (b), but retain her theism, she still faces Lovering's argument against theistic noninferentialism (see footnote 5). ${ }^{17}$ The smallest damage for a theistic inferentialist qua theist, however, would be to retain (a) and (b) and to reject (c), i.e. to reject the claim that inferential evidence is discoverable not simply in principle, but in practice.

What would such a rejection look like? In order to see that, we first need to take a closer look at (c). As noted, for Lovering evidence for $\mathrm{X}$ is discoverable in principle provided the evidence exists. And evidence for $\mathrm{X}$ is discoverable in practice provided it falls within the range of human experience. As we shall now show, however, it is debatable when evidence for $\mathrm{X}$ falls within the range of human experience. Let us reconsider Lovering's example of a sound that is evidence for a goblet, but falls outside the human hearing range. Why should we think that the evidence really falls outside that range? After all, we can easily imagine a hearing aid, or some other device, that would make the evidence, somehow, accessible to someone's experience. If Jane has such a device, but Jack has not, then for Jane the evidence is discoverable in practice, but not for Jack. Hence, being discoverable in practice must be relativized to

16 Alvin Plantinga, Warranted Christian Belief (OUP, 2000).

17 Lovering's argument against this kind of theism (that proceeds from the problem of divine hiddenness, Lovering, God and Evidence, 41-62) lies beyond the scope of this paper. There are, however, interesting responses to the problem of divine hiddenness that Lovering doesn't discuss: see the papers by Murray, Garcia, Wainwright, Moser, and Kvanvig in Daniel Howard-Snyder and Paul K. Moser, eds., Divine hiddenness: New essays (CUP, 2002); see also Peter van Inwagen, The Problem of Evil: The Gifford Lectures 2003 (Clarendon Press, 2006), Lecture 8. 
persons. Moreover, suppose Jane has the device but she is in coma; should we then say that for her, in that condition, the evidence for the goblet is discoverable in practice? It would seem not. Hence, being discoverable in practice must be relativized to conditions as well. The problem with (c) is that it doesn't contain these relativizations. Incorporating these in (c), we get

$\left(c^{\star}\right)$ that this evidence for God's existence exists, but it is not always accessible for everyone in every condition.

The case for $\left(c^{*}\right)$ can be strengthened. Think of Fermat's famous Last Theorem that was eventually proved by Andrew Wiles. Most contemporary professional mathematicians are unable to follow all the details of Wiles' proof. ${ }^{18}$ Of course, in other conditions, e.g. the condition of having studied the proof intensely, or the condition of having improved mathematical powers, the evidence for the Last Theorem is accessible, i.e. discoverable in practice. But for many mathematicians, being in the conditions they are in, and having the mathematical powers they have, the evidence is not accessible, i.e. not discoverable in practice.

Where does this leave us? Here: a theistic inferentialist qua theist can happily accept Lovering's conclusion, so accept that one of the theist's inferentialist's presumed defining beliefs (as defined by Lovering) is false. For a theist can happily grant that (c) should be rejected - it is untenable! This means that no theist, not even a theist who believes there is evidence for God's existence, should be shaken by Lovering's conclusion - but rather endorse it. This situation is brought about by the fact that Lovering hasn't specifically argued for the falsity of either (a), or (b) or (c), and presumable has not realized that (c) is not as plausible to a theist as he anticipated it would be. He thus leaves space to the theist to reject (c) and hence enables her to agree with his conclusion that was intended against the theist!

To this we may add that someone who accepts (a) and (b), rejects (c) but accepts $\left(c^{\star}\right)$, still qualifies as a theistic inferentialist, albeit not in the way defined by Lovering. Lovering's criticism concerns a rather extreme, and

18 This is not to deny that many contemporary mathematicians have knowledge enough of some high-level ideas that enables them to intuitively see how the proof works and what it involves. But this contrasts with knowing the intricacies of the proof. On this difference see William P. Thurston, "On Proof and Progress in Mathematics", in 18 Unconventional Essays on the Nature of Mathematics, ed. Reuben Hersh (Springer, 2006). 
as we argued untenable, version of theistic inferentialism, as it includes the problematic belief in (c). A weaker and more plausible version of theistic inferentialism, one including $\left(c^{\star}\right)$, however, is left unscathed by anything that Lovering has said.

So, a theist could happily accept Lovering's conclusion by rejecting (c) and, by adopting $\left(c^{\star}\right)$ still qualify as a modest theistic inferentialist.

We could leave it at this. But that could look cheap. For Lovering's argument is informed by ideas, incorporated in premises $\mathrm{P} 1$ and $\mathrm{P} 2$, that merit further attention, even if they aren't part of an argument whose conclusion should give a theist, not even a (modest) theistic inferentialist, pause. For these premises do contain ideas that are problematic for theists. We now argue that $\mathrm{P} 1$ and $\mathrm{P} 2$ are problematic as they stand, and should not be accepted.

\section{(b) Premise P1}

Premise P1 ("Theistic inferentialists have failed to convince 85 percent of their intellectual peers") states an alleged fact. The evidence for it is the Bourget/Chalmers survey - a survey of the beliefs of professional philosophers from reputable institutions in mainly the Anglo-Saxon world, esp. the U.S. ${ }^{19}$ In this section we argue that this survey does not support the alleged fact that theistic inferentialists have failed to convince 85 percent of their peers, and hence that P1 cannot taken to have been established by Lovering. Crucial to our argument is a certain understanding of what it is for one person to fail to convince another ${ }^{20}$ :

$S$ failed to convince $S^{*}$ that $p$ is the case iff: (i) $S$ presented evidence in favor of $\mathrm{P}$ to $\mathrm{S}^{*}$ in such a way that $\mathrm{S}^{*}$ became aware of the evidence, (ii) $S^{*}$ seriously studied the evidence, and (iii) $S^{*}$ wasn't convinced by the evidence that $\mathrm{p}$ is the case.

To work our way to our argument, we consider the survey in somewhat more detail. Philosophers from elite $\mathrm{PhD}$ granting departments mainly in the English-speaking world were asked to answer no less than 30 question,

19 See Bourget and Chalmers, "What do philosophers believe?". The survey was sent to all regular faculty members of 99 leading departments of philosophy. Of these, seven were located in non-English speaking countries in continental Europe. The total target group consisted of 1972 philosophers of whom $931(47,2 \%)$ responded.

20 Lovering offers no analysis of this phrase. 
such as "Apriori knowledge: yes or no?", "Abstract objects: yes or no?", "Free will: compatibilism, libertarianism, or no free will?", and also "God: theism or atheism?" This latter question was answered as follows ${ }^{21}$ :

\begin{tabular}{|r|l|}
\hline Atheism & $73 \%$ \\
\hline Theism & $15 \%$ \\
\hline Agnostic/undecided & $12 \%$ \\
\hline
\end{tabular}

This overview indicates that 85 percent does not accept theism.

Although this is isn't going to affect our argument directly, it is highly relevant to point out that these numbers are problematic in that they are obtained from a survey among philosophers from only elite departments mainly in the English-speaking world. For Neil Gross and Solon Simmons found that people at elite institutions are less religious than people in the academy in general. ${ }^{22} \mathrm{~A}$ more representative sample of philosophers, e.g. also coming from small liberal arts colleges and state colleges that only offer undergraduate degrees, would have given less skewed numbers. ${ }^{23}$

Can it be concluded, on the basis of the survey, that theistic inferentialists have failed to convince 85 percent of their intellectual peers, as P1 has it? It seems not - at least, not on our plausible analysis of "failed to convince". For the survey doesn't indicate that the participants satisfy conditions (i) and (ii). I.e. the survey doesn't provide evidence that the participants were aware of the theistic arguments, nor that they have seriously studied them. It is certainly the case that the examples of theistic inferentialists philosophers Lovering mentioned (St. Augustine, Anselm, Thomas Aquinas, William Paley, Richard Swinburne, Alvin Plantinga, Robin Collins, and William Lane Craig) presented their arguments with the goal of convincing their epistemic peers.

21 Ibid., 476, percentages rounded.

22 Neil Gross and Solon Simmons, "The Religiosity of American College and Univ. Professors", Sociology of Religion 70, no. 2 (2009). Gross and Simmons draw their conclusions from a survey among full time college and Univ. professors in the USA. They do not mention how many people were contacted but they got a response of 1417 . The results of the top 50 universities in the U.S. News and World Report Ranking were compared to other institutions. Participants could choose between the statements 'I don't believe in God'; 'I don't know whether there is a God'; 'I do believe in a higher power'; 'I find myself believing in God some of the time'; 'While I have doubts, I feel that I do believe in God'; 'I know God really exists and I have no doubts about it'.

23 Ibid. found that the majority of professors, even at elite institutions, are religious believers. 
It is, however, not unreasonable to think that their arguments only reached a limited number of epistemic peers. In the current academic climate it is not unlikely that publication pressure forces academics to focus their research (very) narrowly and hence to not familiarize themselves with theistic evidence if this lies outside of their research focus. This means that the survey, strictly speaking, provides no evidence for the proposition that theistic inferentialists have failed to convince their peers. Hence, P1 cannot be considered to be established by the evidence adduced. ${ }^{24}$

Lovering might respond that there are philosophers who we know were or are familiar with most or the most important arguments for the existence of God but were not convinced. ${ }^{25}$ However, this is too small a minority to conclude that the theistic inferentialists have failed to convince the majority of academic peers.

24 Also, it is unlikely that those who accept or lean towards atheism and who have indeed studied the inferential evidence for theism, have studied all or even most of the evidence that has been adduced by theistic inferentialists - and such arguments are numerous. Alvin Plantinga listed 25 arguments, most of them dependent on different evidence, cf. Alvin Plantinga, “Two Dozen (or so) Theistic Arguments: Lecture Notes", (unpublished manuscript, 1986). The recent Blackwell Companion to Natural Theology lists 11 arguments, each of them involving different sorts evidence, see William L. Craig and James P. Moreland, eds., The Blackwell Companion to Natural Theology (Wiley-Blackwell, 2009). And especially the ontological and cosmological arguments have a great number of variants (for a survey of ontological arguments, see Plantinga Alvin Plantinga, ed., The Ontological Argument from St. Anselm to Contemporary Philosophers (Macmillan, 1968), and Mirosław Szatkowski, ed., Ontological Proofs Today (Ontos, 2012); for a survey of cosmological arguments, see William Lane Craig, The cosmological argument from Plato to Leibniz (Macmillan, 1980), and Emanuel Rutten, Towards a Renewed Case for Theism: A Critical Assessment of Contemporary Cosmological Arguments ([S.l.: s.n.], 2012). As it is unlikely that the majority of philosophers accepting or leaning towards atheism are familiar with most of the inferential evidence for the existence of God, it cannot be claimed that the evidence fails to convince the majority of philosophers. For failing to convince, on our plausible analysis, requires awareness of the evidence and a serious study of it. But these remarks are strictly speaking beside the point - the point being that the Bourget/Chalmers survey simply offers no evidence that conditions (i) and (ii) for 'failing to convince' are satisfied, and hence cannot be adduced as evidence for P1 ("Theistic inferentialists have failed to convince 85 percent of their intellectual peers").

25 E.g. J. L. Mackie, The Miracle of Theism: Arguments for and Against the Existence of God (Clarendon Press, 1982), Nicholas Everitt, The non-existence of God: An introduction (Routledge, 2003), Graham Oppy, Arguing about Gods (CUP, 2006), and Herman Philipse, God in the Age of Science? A Critique of Religious Reason (OUP, 2012). 
Lovering might also respond that theistic inferentialists had ample time to convince their epistemic peers. The fact that their arguments have been around for centuries combined with the fact that after all those centuries few academic philosophers consider themselves theists could yield a negative verdict on the theistic inferentialist's defining beliefs, especially on (a). We respond by noting that St. Augustine, Thomas Aquinas and many other likely did succeed in convincing many of their contemporary and even many of their subsequent epistemic peers. Hence, a reference to the long history of theistic arguments does not support P1, but rather weakens it. Reference to the long history of theistic arguments also does little to evade the problems with P1 that we discussed above. Notwithstanding the fact that these arguments have a long history, it is still not unlikely that many current academic philosophers have not studied many, or most, theistic arguments. Furthermore, some theistic arguments are of relatively recent date - for example Moreland's argument from consciousness. ${ }^{26}$ No argument from having a long history (if such an argument would be compelling at all) has a grip on such recent arguments.

There is, moreover, empirical evidence relevant to this issue that was available to Lovering, but that he has not taken into consideration. The Bourget/Chalmers survey indicates that among philosophers who specialize in the philosophy of religion (and hence are more likely to have studied the evidence in detail), 73 percent lean toward or accept theism..$^{27}$ But this means that if the following is a good argument

The fact that 85 percent of philosophers don't believe in God is best explained by supposing that at least one of the theistic inferentialists' defining beliefs is false,

then the following argument must be equally good:

The fact that 73 percent of philosophers of religion are theists, is best explained by supposing that the theistic inferentialists' defining beliefs are true.

26 James P. Moreland, “The argument from consciousness", in The Blackwell Companion to Natural Theology, ed. William L. Craig and James P. Moreland (Wiley-Blackwell, 2009). The argument claims that the phenomenon consciousness is best explained by God's existence.

27 Bourget and Chalmers, "What do philosophers believe?", 482. 
It might in fact even be better, for philosophers of religion may be thought to be the experts on arguments for God's existence.

One might, however, be sceptical about this last suggestion for the following reason: the overrepresentation of theists in the philosophy of religion might indicate that theists are too much influenced by prior beliefs when they evaluate religious arguments. It might indicate a confirmation bias. ${ }^{28}$

In order to evaluate this, another recent survey is relevant, one conducted by De Cruz and De Smedt. ${ }^{29}$ Their survey confirmed the findings of Bourget/Chalmers: among philosophers of religion the percentage of theists is high - some 73 percent. This survey presented eight arguments for theism, and eight arguments for atheism, and participants (who were recruited through philosophy mailing lists) were asked to rate the strength of these arguments. Participants were also asked to indicate their philosophical area of specialization, and whether they identified themselves as 'theist', 'atheist', or 'agnostic/undecided'. One outcome of the survey is that theists rated arguments that support theism significantly higher than atheists. Another outcome is that atheists rated arguments against theism significantly higher than theists. In fact De Cruz and De Smedt found a strong correlation between religious belief (or lack thereof) and the assessment of arguments. So, if there is a confirmation bias, it works both ways, which takes the sting out of Draper's and Nichols's argument. DeCruz and De Smedt conclude: "We thus found a confirmation of our prediction that religious belief significantly influences the evaluation of religious arguments: theists, atheists and agnostics differ in how they evaluate arguments for and against the existence of God. The results are highly significant overall."

The main conclusion of this section is that the evidence that Lovering offers in order to established P1 is insufficient to the task. The secondary conclusion is that if Lovering's case for P1 is deemed to be compelling, then an

28 This has been suggested by Paul Draper, Ryan Nichols, and Sherwood J. B. Sugden, "Diagnosing Bias in Philosophy of Religion", Monist 96, no. 3 (2013).

29 Helen de Cruz and De Smedt Johan, "How do philosophers evaluate natural theological arguments? An experimental philosophical investigation", in Advances in religion, cognitive science, and experimental philosophy, ed. Helen Cruz and Ryan Nichols, Advances in experimental philosophy (Bloomsbury, 2016) The survey was completed by 802 participants of which 82 percent were professional philosophers. 40.5 percent self-identified as theists and 40.4 as atheists. The remaining 19.1 self-identified as agnostics. 
analogous case for the conclusion that the theistic inferentialist's beliefs are true can be deemed equally or even more compelling.

(c) Premise P2

Lovering devotes most of his attention to premise P2: "The best explanation of the fact that the vast majority of philosophers remain unconvinced by the theistic inferentialists is that at least one of the inferentialists' defining beliefs is false."

Since P2 makes a comparative claim about what best explains a certain fact, if we want to evaluate $\mathrm{P} 2$ we will have to compare various explanations and estimate their relative strengths.

Note that Lovering doesn't hold

Falsity Explains Disbelief: If most people disbelieve P, that fact is best explained by P's falsity,

which is a principle that is clearly false, as the following example bears out: at one time most people disbelieved heliocentrism, but this fact, surely, is not best explained by heliocentrism's falsehood. Rather, Lovering adopts something like the following principle

Most Experts Don't Believe Falsehoods (MEDBF): if a majority of the experts (so people who are experts in a field to which $\mathrm{P}$ belongs) don't believe in $\mathrm{P}$, this fact is best explained by P's falsity.

Should we accept MEDBF? There seem to be fields where this principle is clearly true. For example, in the field of climate studies, the vast majority of experts don't believe the proposition that there is no global warming; and you might think that this is best explained by that proposition's falsity. Likewise, in the field of cosmology, experts don't believe in geocentrism; and this, again is best explained by geocentrism's falsehood. But there seem to be other fields, economics and psychiatry are examples, where the numbers of dissenting experts rise. If a majority of 60 percent economists disbelieve Keynesianism, then this fact is not obviously best explained by Keynesianism's falsity. This is just to say that in this field MEDBF isn't clearly true. We ask: what accounts for this difference? We answer: the difference is accounted for by the availability, in a field, of established facts. Climate science, cosmology and other natural sciences have conjured up innumerably many established facts. Economics and psychiatry less so. Intuitively, differ- 
ent fields of study can be placed on a continuum that measures the number of established facts in a field. And now the following principle commends itself (again at an intuitive level): the more established facts a field counts, the more MEDBF will be true of experts in that field, and the less established facts a field counts, the less MEDBF will be true of experts in that field.

Now P2 betrays a commitment to MEDBF. This raises the question to what degree MEDBF is true in the field in which Lovering is moving. That is to say: is the field of philosophy such that the experts in it are such that MEDBF is true of them? For an answer we need to ask whether philosophy has conjured up established facts. The answer, we fear, must be: not very many. Philosophy in general and metaphysics and epistemology in particular are not fields with many established facts, and they are hence unlike climate science and cosmology. Because of this the study of them doesn't seem to provide us with information about parts and aspects of the world. This is familiar to every working metaphysician and epistemologist. ${ }^{30}$ There are no established facts about, say, the existence of universals (nominalists and realists still disagree), the existence of time (endurantists oppose perdurantists), the relation between minds and bodies (dualism is by no means a dead option), etc. There are no established facts about the nature of knowledge, the nature of justification, about whether internalism or externalism is correct, about whether contextualist views of knowledge state it like it is etc. This is not to deny that there are metaphysical or epistemological facts. But it is to deny that there are many established metaphysical or epistemological facts.

One problem with $\mathrm{P} 2$, then, is that it assumes MEDBF and MEDBF is only applicable to philosophy if we assume that there are established philosophical facts, of which there aren't many.

Where does this leave us with respect to Lovering's preferred explanation of the fact that the vast majority of philosophers remain unconvinced by the theistic inferentialists - the explanation being that at least one of the inferentialists' defining beliefs is false (= explanation \#5)? Here: \#5 assumes that MEDBF true in the field of philosophy. We have thrown cold water on this assumption, and hence on \#5, and hence on P2.

30 See for instance Peter van Inwagen, Metaphysics, 3rd ed. (Perseus, 2009), 10-11; David J. Chalmers, David Manley and Ryan Wasserman, eds., Metametaphysics: New essays on the foundations of ontology (OUP, 2009) is testimony of the fact. This point is less acknowledged by epistemologists. 
Explanation \#5 raises another worry that Lovering does not even address. If the best explanation of the fact that 85 percent of the philosophers remain unconvinced by the theistic inferentialists is that some of the theistic inferentialists' defining beliefs are false, the question arises: what explains the fact of the other 15 percent? If the explanation for not believing "God exists" is the falsity of that proposition, then what can the explanation for believing that proposition be? Lovering could argue that the $15 \%$ made an (honest) mistake. This response, however, is weak because 15\% of 1972 philosophers still amounts to a significant number which stands in need of an explanation. Neither can the explanation be that "God exists" is true, for it is presumed to be false. This leaves us, probably, with the usual suspects, i.e. explanation in terms of projection, childhood-neurosis, evolutionary by-product or adaptation etc. However, Lovering has barred that way for himself. For when he discusses explanations \#1 and \#2 of the fact that 85 percent remain unconvinced-explanations that involve theological doctrines like the Calvinist doctrine of total depravity, or the doctrine that sin impairs both intellect and will - he says: "if theistic inferentialists were to believe that nontheistic philosophers are ... inferior by simply assuming a theology to be true, nontheistic philosophers could likewise assume an atheology to be true, one that entails that theistic inferentialists are the ones who are dispositionally inferior. This would ... do nothing more than lead to an impasse." ${ }^{11}$ But if this is Lovering's line, then he cannot give an explanation for the remaining 15 percent. $^{32}$ And if, his own words notwithstanding, he would attempt such an explanation, then, by parity of reasons, the theist must be allowed her explanation of the 85 percent fact. This means that the other explanations, that Lovering deems inadequate, are back on the table. And so now the question to consider is whether \#5 is really the best explanation of the 85 percent fact - i.e. an explanation that is better than its competitors \#1-4, or than any other possible explanation that Lovering has not listed.

Is explanation \#5 ('at least one of the inferentialist's defining beliefs is false' - and here we concentrate on (a) and (b), and leave (c), which is, as

31 Lovering, God and Evidence, 27.

32 Lovering could still argue that the $15 \%$ simply made a mistake but he cannot make this claim without assuming the falsity of theism. 
we have argued untenable, out of consideration) better than explanation \# 1 ('nontheistic philosophers are intellectually inferior to their theistic colleagues')? We have argued that \#5 is unsatisfactory. Is it nonetheless better than \#1? Well, \#1 itself isn't plausible either: there is no empirical evidence that indicates that non-theists are intellectually inferior (or superior) to theists. Is nonetheless one of them the better of the two? On the basis of what we have said so far, this cannot be decided.

Is perhaps explanation \#2 ('nontheists are somehow culpably ignorant of the evidence of God's existence, perhaps due to the lack of a receptive attitude, ${ }^{33}$ or due to the noetic effects of $\sin ^{34}$ ) better than either explanation \#1 or explanation \#5? Lovering claims that it is unlikely that nontheistic philosophers en masse wilfully reject evidence for God's existence or refuse to consider it. He affirms that a similar claim as explanation \#2 in other domains of philosophy would not be convincing. For example, it would not be appropriate if theistic inferentialists were to explain disagreements with nontheistic philosophers over ethics by claiming the latter are culpably ignorant by lacking a receptive attitude or the cognitive effects of sin. However, we think that lacking in receptive attitude, and cognitive effects of sin, may very well be a better explanation than \#1 or \#5. And this for a number of reasons. Firstly, wilfully rejecting theism is not the same as lack of a receptive attitude or suffering from noetic effects of sin (as Lovering seems to suggest). Wilful rejection suggests a conscious decision not to give the evidence of God's existence the attention it deserves. Lovering cites Paul Moser and Alvin Plantinga as authors who argued for something like explanation \#2. Especially Plantinga's explanation does not fit Lovering's framing as 'wilful rejection' well. Plantinga suggests that nontheistic philosophers remain unconvinced because of the noetic effects of sin. Being subject to the noetic effects of sin does not mean that people consciously reject evidence for God's existence. They rather find themselves in a state where the force of the evidence is not clear to them. Moser's suggestion of a lack of receptive attitude on behalf of nontheistic philosophers also does not amount to a conscious decision not to give the evidence its fair due. On his view, a receptive atti-

33 Paul K. Moser, "Cognitive Idolatry and Divine Hiding”, in Howard-Snyder; Moser, Divine Hiddenness.

34 Plantinga, Warranted Christian Belief. 
tude encompasses much more than an intellectual decision but also a change in one's direction of life and priorities. ${ }^{35}$ Lovering only argues against the stronger claim of wilful rejection. He gives no argument against the possibility of noetic effects of sin or a lack of receptive attitude among nontheistic philosophers. If there is theistic inferential evidence, the fact that not all philosophers are theists may at least in part be explained by a lack of receptive attitude, or cognitive effects of sin. There is also reason to think that culpable ignorance may be more an issue in the debate over God's existence than in other debates in philosophy. As Plantinga has said, the cognitive effects of sin may have an effect on knowledge of God above anything else. ${ }^{36}$ Another reason for taking $\# 2$ seriously is that inferentialist evidence alone may only very rarely be sufficient for conviction. An analogy with moral psychology illuminates our point. It has been argued that certain moral truths cannot be believed by persons who lack certain emotions - even when those truths are presented to them with rigor, force and show of argument. The presence of such emotions is a necessary condition for someone to acquire the moral belief in question. ${ }^{37}$ Something similar may be true for theistic belief. This means that in addition to the explanation of the 85 percent fact in terms of lack of receptive attitude and cognitive effects of sin, the explanation may be in terms of the absence of certain emotions. Studies on persons with autism spectrum disorder confirm this point and suggest that they lack the necessary emotions concerning mind reading to be receptive for religious belief. ${ }^{38} \mathrm{~A}$ recent cognitive theory of atheism elaborates on this. Gervais and Norenzayan suggested that the intuitive processes leading to religious belief

35 Moser writes: "We need a change of receptive attitude to apprehend the available evidence in the right way. This change involves the direction of our lives, including our settled priorities, not just our intellectual assent.", in Paul K. Moser, "Divine Hiddenness Does Not Justify Atheism", in Contemporary Debates in Philosophy of Religion, ed. Michael L. Peterson and Raymond J. Vanarragon, (Blackwell, 2004), 47.

36 Plantinga writes: "Our original knowledge of God [...] has been severely compromised [...]. [B] ecause of the fall, we no longer know God in the same natural and unproblematic way in which we know each other and the world around us." Plantinga, Warranted Christian Belief, 205.

37 Shaun Nichols, Sentimental Rules: On the Natural Foundations of Moral Judgment (OUP, 2004); Jesse Prinz, "The emotional basis of moral judgments", Philosophical Explorations 9, no. 1 (2006).

38 Ara Norenzayan and Will M. Gervais, “The origins of religious disbelief”, Trends in cognitive sciences 17 , no. 1 (2013). 
can be revised or overruled by analytic processes. Results from priming experiments confirmed their theory. ${ }^{39}$ Their point was confirmed by two other studies. ${ }^{40}$ Since religious belief requires more emotional or imagination like styles of thinking, an overemphasis on analytic thinking is likely to make people less receptive for belief in God. One could thus argue that doing a certain kind of analytic philosophy, like logic, formal epistemology or formal philosophy of science, makes some philosophers less receptive for belief in God. It is also possible that non-theists lack a receptive attitude due to confirmation biases as De Cruz and De Smedt have argued. ${ }^{41}$

One may very well think that this (augmented) explanation \#2 is better than $\# 1$ and $\# 5$, as there is empirical evidence for it, which there is not for Lovering's preferred but inadequate $\# 5$, nor for \#1. Moreover, \#2 is fully compatible with the questionnaire evidence. To take \#2 as a live option does not entail that if it is a correct, it provides a complete explanation of the 85 percent fact. Perhaps for some nontheistic philosophers \#2 provides the complete explanation, whereas for others it provides a partial explanation at best.

In cases where explanation $\# 2$ provides only a partial explanation, \#4 ('theistic inferentialists have inadequately presented the evidence') may do additional explanatory work. There is no reason to think that inferentialists always present their evidence in the best of ways. We return to this point below. This may explain at least in part why they have failed in convincing their nontheistic peers. \#4 also has the virtue of being fully compatible with the 85 percent fact. There is no need to ask whether \#4 is a better explanation than \#2, as they may both be correct.

As to \#3 ('God prevents nontheistic philosophers from noticing the inferential evidence') theists may have theological reasons for thinking this may be true in some cases. For example, in response to the problem of divine hiddenness a number of theistic philosophers have argued that God

39 Will M. Gervais and Ara Norenzayan, "Analytic Thinking Promotes Religious Disbelief", Science 336, no. 6080 (2012).

40 Gordon Pennycook et al., "Analytic cognitive style predicts religious and paranormal belief”, Cognition 123, no. 3 (2012).

41 Cruz and De Smedt Johan, "How do philosophers evaluate natural theological arguments? An experimental philosophical investigation”. 
hides himself to allow for free moral actions or spiritual growth. ${ }^{42}$ Again, this explanation needn't compete with \#2 and \#4: all three of them may in some cases be partially true. Lovering's problem with this explanation is that it seems ad hoc. He returns to his goblet analogy and writes: "Suppose the believers explained their failure to make their case to the skeptics on the grounds that evidence of the goblet may be found only by those who already believe - or are disposed to believe - that the goblet exists. This may be true, but looking in from the outside, such an explanation appears ad hoc." ${ }^{43}$ Our examples suffice to show that explanation \#3 is not ad hoc. God can have reasons to hide himself and hence prevent (some) nontheistic philosophers from noticing inferential evidence for his existence.

Explanation \#4 ('Theistic inferentialists have discovered evidence of God's existence, but they have been unable to adequately articulate this evidence to their sceptical counterpart') is also not as implausible as Lovering claims. Lovering himself gives two examples of theistic inferential evidence that is very difficult to understand, viz. William Craig's cosmological argument that relies on 'metaphysical time' and Alvin Plantinga's modal ontological argument. Lovering, however, argues that a God who would want to let himself be known would not solely rely on very difficult evidence. He argues that this explanation conflicts with God's goodness, as it is very unlikely that God would only let his existence be known through complicated evidence. He adds that at least some theistic inferentialists appear very skilled in articulating the evidence for God's existence (his examples are Richard Swinburne, William Craig and Thomas Aquinas). Since we do not argue that explanation \#4 by itself can explain the small number of convinced philosophers, we need not deny that at least some theistic inferentialists were able to present the evidence adequately. Since the impact of one philosopher is limited, it is likely that not all philosophers know about the arguments of skilled philosophers like Swinburne, Craig and Aquinas (this especially holds for the first two). Some nontheistic philosophers might only have heard arguments by less skilled philosophers.

42 E.g. Michael J. Murray, "Deus Absconditus", Laura L. Garcia, "St. John of the Cross and the Necessity of Divine Hiddenness", both in Howard-Snyder; Moser, Divine Hiddenness.

43 Lovering, God and Evidence, 28. 
Lovering also neglects the fact that philosophical arguments in general have become more complex during the last decades. For example, whereas arguments for moral realism were fairly straightforward for a good part of the history of philosophy, recent versions are far more intricate. Theistic arguments are no different. This is mainly a result of counterarguments that led to refinements and more nuance. As a result, many philosophical arguments are harder to understand, not necessarily because defenders lack skill but mainly because understanding them requires more training and background knowledge.

As to Lovering's point that God's goodness conflicts with difficult evidence, we note that there is no conflict. Lovering's point is that a good God would provide clear and simple evidence for his existence. A God that only allows for complicated evidence will remain hidden for many people and this is a problem for any claim to his goodness. However, Lovering's argument is about academic philosophers. Since academic philosophers can be expected to understand, in principle, difficult philosophical evidence, God is not putting unreasonable demands on them when the evidence for his existence is complicated.

What we suggest, then, is that the conjunction of explanations \#2, \#3, and \#4 provide a better explanation of the 85 percent fact than \#5 and \#1 for quite obvious reasons. First, \#5, as we have suggested earlier on, doesn't really explain anything, whereas the conjunction of explanations does. Moreover, whereas there is no empirical evidence for $\# 5$ or \#1, there is some empirical evidence for the conjunctive explanation.

Lovering could respond that explanation \#5 is a more simple explanation than a conjunction of explanation \#2, \#3 and \#4 and that \#5 is therefore a better explanation. The criterion of simplicity however only holds if all other things are equal. But in this case they are not equal. For we have argued that \#5 fails for independent reasons.

\section{ONE MORE PROBLEMATIC FEATURE OF THE ARGUMENT}

The point we will be making in this section regards an 'ingredient' of Lovering's argument that is neither a premise, nor a conclusion. Perhaps it can be thought of as an implicit background assumption. The point concerns the relation between probability and conviction, or better: the relation between probability and the power to convince. Lovering clearly assumes that if evidence is probabilifying, then it is (also) convincing evidence, i.e. then it (also) 
has the power to convince persons - perhaps not just any person, but certainly the well-educated rational person. We argue against this by providing a counter example that stands for a whole class of like cases. The example shows that the fact that a piece of inferential evidence for claim $C$ fails to convince any (or many) persons, doesn't entail that the inferential evidence isn't therefore good evidence for C. It is supposed to show that there can be (very) good probabilifying evidence for propositions that are not widely believed.

The example comes from the history of science. Copernicus provided inferential probabilifying evidence for heliocentrism. Nonetheless, his evidence didn't convince very many of his contemporaries. Heliocentrism was not widely accepted until well into the $18^{\text {th }}$ century. Yet few people will deny that Copernicus adduced probabilifying evidence for heliocentrism. Other examples are easy to come by.

But if this is correct, so if the fact that evidence fails to convince doesn't mean that the evidence therefore isn't good probabilifying evidence, this is an additional reason to be sceptical about Lovering's argument. After all, Lovering suggests that if the evidence adduced by theistic inferentialists doesn't convince 85 percent of the philosophers, this means (because it is best explained that way) that the evidence adduced isn't probabilifying evidence. But we have seen that this is wrong. And it better be. For Lovering's assumption, if true, would be a most effective science stopper, as the heliocentrism case brings out. New ideas, also in science, will as a rule always meet with resistance and rejection, even if the evidence for them is probabilifying. Hence, a background assumption of Lovering's argument should be rejected for reasons that having nothing to do with religious belief.

\section{CONCLUSION}

By way of conclusion, then, we have argued that:

- An theistic inferentialist can gladly accept the conclusion of Lovering's argument ("It is probably true that at least one of theistic inferentialist's defining beliefs (a), (b), and (c) is false or cognitively meaningless"). She can accept that without giving up (a) and (b), viz. if she gives up (c), for which there is solid reason. She can still continue to be a theistic inferentialist, in a somewhat weaker sense, viz. by adopting the independently plausible $\left(c^{*}\right)$. 
- Premise P1 ('Theistic inferentialists have failed to convince the vast majority (i.e. 85 percent) of their intellectual peers') has not been shown by the evidence to be true, as the evidence that is adduced doesn't indicate that those who have filled out the questionnaire have actually seriously studied the inferentialists' evidence.

- Premise P2, about what best explains the 85 percent fact, has not been established as it relies on the problematic assumption that MEDBF (the principle that says that most experts don't believe falsehoods) is applicable to philosophy, which assumes there are established philosophical (metaphysical and epistemological) facts. This is problematic in that there are very few established philosophical facts.

- Premise P2 seems in fact false: \#5 just doesn't seem the best explanation of the 85 percent fact. The conjunctive explanation of \#2, \#3, and \#4, for all the evidence indicates, does a better job.

- The argument presupposes that if evidence is probabilifying, it is convincing evidence. This presupposition, if true, would be a most effective science stopper. But it isn't true. ${ }^{44}$

\section{BIBLIOGRAPHY}

Ayer, Alfred Jules. Language, Truth and Logic. New York, NY: Dover Publications, 2012 [1952].

Bourget, David, and David J. Chalmers. "What do philosophers believe?" Philosophical Studies: An International Journal for Philosophy in the Analytic Tradition 170, no. 3 (2014): 465-500. doi:10.1007/s11098-013-0259-7.

Chalmers, David John, David Manley, and Ryan Wasserman, eds. Metametaphysics: New Essays on the Foundations of Ontology. Oxford, New York: Oxford University Press, 2009.

44 For discussion and comments on earlier versions of this paper we thank Gijsbert van den Brink, Rik Peels, Jeroen de Ridder, Naomi Kloosterboer, Lieke Asma, Leon de Bruin, Gerrit Glas, Emanuel Rutten, and two anonymous reviewers fort this journal. We also thank the Templeton World Charity Foundation for a generous grant that made this paper possible. For the views argued for in this paper, however, only the authors are responsible. 
Christensen, David. "Epistemology of Disagreement: The Good News." The Philosophical Review 116, no. 2 (2007): 187-217. doi:10.1215/00318108-2006-035.

Craig, William Lane. The Cosmological Argument from Plato to Leibniz. London: Macmillan, 1980.

Craig, William Lane and James Porter Moreland, eds. The Blackwell Companion to Natural Theology. Chichester, U.K., Malden, MA: Wiley-Blackwell, 2009.

Cruz, Helen de, and De Smedt Johan. "How do philosophers evaluate natural theological arguments? An experimental philosophical investigation." In Advances in Religion, Cognitive Science, and Experimental Philosophy, ed. by Helen de Cruz and Ryan Nichols. London, UK, New York, NY, USA: Bloomsbury Academic, 2016.

Douven, Igor. "Abduction." In Stanford Encyclopedia of Philosophy, ed. by Edward N. Zalta. Spring 2011. http://plato.stanford.edu/archives/spr2011/entries/abduction/.

Draper, Paul, Ryan Nichols, and Sherwood J. B. Sugden. "Diagnosing Bias in Philosophy of Religion." Monist 96, no. 3 (2013): 420-46. doi:10.5840/monist201396319.

Everitt, Nicholas. The non-existence of God: An Introduction. London: Routledge, 2003.

Frances, Bryan. Disagreement. Cambridge: Polity, 2014.

Garcia, Laura L. "St. John of the Cross and the Necessity of Divine Hiddenness." In Howard-Snyder; Moser, Divine Hiddenness, 83-97.

Gervais, Will M., and Ara Norenzayan. "Analytic Thinking Promotes Religious Disbelief." Science 336, no. 6080 (2012): 493-96. doi:10.1126/science.1215647.

Gross, Neil, and Solon Simmons. "The Religiosity of American College and University Professors." Sociology of Religion 70, no. 2 (2009): 101-29. doi:10.1093/socrel/srp026.

Howard-Snyder, Daniel and Paul K. Moser, eds. Divine Hiddenness: New Essays. Cambridge, UK, New York, NY: Cambridge University Press, 2002.

Kornblith, Hilary. "Belief in the Face of Controversy." In Disagreement, ed. by Richard Feldman and Ted A. Warfield. 1st ed., 29-52. Oxford University Press, 2010.

Lipton, Peter. "Is the Best Good Enough?" Proceedings of the Aristotelian Society 93 (1993): 89-104. http://www.jstor.org/stable/4545167.

Lovering, Rob. "The Problem of the Theistic Evidentialist Philosophers." Philo 13, no. 2 (2010): 185-200. doi:10.5840/philo20101325.

-. God and Evidence: Problems for Theistic Philosophers. London: Bloomsbury, 2013. 
Mackie, J. L. The Miracle of Theism: Arguments for and Against the Existence of God. Oxford, New York: Clarendon Press; Oxford University Press, 1982.

Moreland, James P. “The argument from consciousness.” In Blackwell Companion to Natural Theology, ed. by William L. Craig and James P. Moreland, 282-343. Chichester, U.K., Malden, MA: Wiley-Blackwell, 2009.

Moser, Paul K. "Cognitive Idolatry and Divine Hiding." In Howard-Snyder; Moser, Divine Hiddenness, 120-48.

-. "Divine Hiddenness Does Not Justify Atheism." In Contemporary Debates in Philosophy of Religion, ed. by Michael L. Peterson and Raymond J. Vanarragon, 4253. Malden, MA: Blackwell Pub, 2004.

Murray, Michael J. "Deus Absconditus." In Howard-Snyder; Moser, Divine Hiddenness, 62-82.

Nichols, Shaun. Sentimental Rules: On the Natural Foundations of Moral Judgment. Oxford: Oxford University Press, 2004.

Norenzayan, Ara, and Will M. Gervais. “The origins of religious disbelief.” Trends in cognitive sciences 17, no. 1 (2013): 20-25. doi:10.1016/j.tics.2012.11.006.

Oppy, Graham. Arguing about Gods. New York, Cambridge: Cambridge University Press, 2006.

Pennycook, Gordon, James Allan Cheyne, Paul Seli, Derek J. Koehler, and Jonathan A. Fugelsang. "Analytic cognitive style predicts religious and paranormal belief." Cognition 123, no. 3 (2012): 335-46. doi:10.1016/j.cognition.2012.03.003.

Philipse, Herman. God in the Age of Science? A Critique of Religious Reason. Oxford: Oxford University Press, 2012.

Plantinga, Alvin. God and other Minds: A Study of the Rational Justification of Belief in God. Ithaca, N.Y.: Cornell University Press, 1967.

-, ed. The Ontological Argument from St. Anselm to Contemporary Philosophers London [u.a.]: Macmillan, 1968.

—. “Two Dozen (or so) Theistic Arguments: Lecture Notes." Unpublished manuscript, 1986.

—. Warranted Christian belief. New York: Oxford University Press, 2000.

Prinz, Jesse. “The emotional basis of moral judgments." Philosophical Explorations 9, no. 1 (2006): 29-43. doi:10.1080/13869790500492466. 
Rutten, Emanuel. Towards a Renewed Case for Theism: A Critical Cssessment of Contemporary Cosmological Arguments. [S.l.: s.n.], 2012.

Szatkowski, Mirosław, ed. Ontological Proofs Today. Frankfurt: Ontos, 2012.

Thurston, William P. "On Proof and Progress in Mathematics." In 18 Unconventional Essays on the Nature of Mathematics, ed. by Reuben Hersh, 37-55. New York, NY: Springer Science+Business, 2006.

van Fraassen, Bas C. Laws and symmetry. Oxford, New York: Clarendon Press, 1989. van Inwagen, Peter. The Problem of Evil: The Gifford Lectures 2003. Oxford, New York: Clarendon Press; Oxford University Press, 2006.

-. Metaphysics. 3rd ed. Philadelphia: Perseus Books Group, 2009. 